DOI: $10.15593 / 2224-9354 / 2021.3 .22$

УДК 614.2

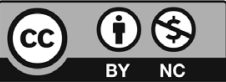

\title{
I.G. Tileva
}

\section{HOW TECHNOLOGIES WILL AFFECT THE FUTURE OF INTERNATIONAL MEDICAL TOURISM}

\begin{abstract}
International tourism is a major sector of the global economy. Some countries owe much of their gross domestic product to various types of tourism including the medical ones. Medical tourism is not typical for every country or region. For this reason certain countries are classified as medical destinations. Over the last few decades, the technological development has changed healthcare at all. However, an important question is what will happen with medical tourism in future. Artificial Intelligence is a prerequisite for a fundamental change in international trade in medical services. Something more, the pandemic situation of 2020 worldwide leads to less realized international travels and less mobility. This creates the need of a change in the way medical services are provided in an international aspect. In order to make a forecast whether the technologies can possibly affect the way of supplying and trading medical services, forecasts for the development of high medical technologies market are summarized. The presented forecasts cover a period between 5 and 10 years and contribute to the conclusions in the article. Compared to the historical development of medical technologies in general an opinion for the future of medical tourism in long-term is expressed.

Keywords: medical tourism, technologies, international trade, medical services, artificial intelligence, patient mobility, supercomputer, robotic surgery.
\end{abstract}

\section{Introduction}

By 2020 the value of medical tourism is estimated at $\$ 10.1$ billion. For comparison in 2017 its total value is $\$ 25.6$ billion. Despite the unprecedented decline in international tourism (65\% decline in first half of 2020) [1] because of Covid-19, the medical tourism is expected to grow at over 12.1\% between 2021 and 2027 [2]. One of the reasons for the growth forecast is the increased awareness regarding medical tourism among patients. In the medical tourism is expected a compound annual growth rate of $21.1 \%$ from 2020 to 2027 [3]. Meanwhile technologies in medicine are evolving rapidly and this is a prerequisite for changing in the way services are provided. Technologies are able to affect not only the quality of the medical treatment and diagnosis but international trade in medical services. The article discusses the standard ways of providing medical services that favor the mobility of people and international medical tourism. Different opportunities that may lead to a decline in medical tourism due to the fundamental change in the way of providing medical services are presented.

According Table 1 in 2016 and 2017 regions with the highest revenues from medical tourism are Europe, Asia Pacific, Latin and North America [4]. By 2020 the

(๑) Tileva I.G., 2021

Ivet G. Tileva - Doctor, Department of International Economic Relations and Business, University of National and World Economy, Sofia, Bulgaria, e-mail: itileva@unwe.bg. 
global platform for organizing medical trips Bookimed ranks the top 10 countries representing medical destinations. According to the classification, the best treatment destinations are Thailand, Turkey, India, South Korea, Germany, Switzerland, Spain, Italy, Israel, Ukraine [5]. It is noted that some countries on different continents have competitive advantages in providing medical services, but in general they are not differentiated into large nearby regions. The improvement of technology and telecommunications is possible to have a serious impact on these countries and whether the economic effects will be positive or negative depends on their development strategy in the medical sector.

Table 1

Global Medical tourism market, by region, 2016-2017

\begin{tabular}{|l|c|c|}
\hline \multicolumn{1}{|c|}{ Region } & 2016 & 2017 \\
\hline North America & $3,202.1$ & $3,308.3$ \\
\hline Europe & $9,682.0$ & $10,537.8$ \\
\hline Asia Pacific & $6,341.4$ & $7,345.9$ \\
\hline Latin America & $3,226.5$ & $3,520.8$ \\
\hline MEA & 766.8 & 936.1 \\
\hline Total & $23,218.8$ & $25,648.9$ \\
\hline
\end{tabular}

\section{Literature review}

For the purposes of the article various sources are used so a different from the standard perspective for the future of medical tourism is given. The sources include scientific articles and books, global reports, international agreements, reputable dictionaries and business analyzes in the field of economics and medicine. Reliable media and medical tourism platforms are also used as an internet sources. The conclusions of the manuscript is made by observations of the rapid development of technologies. International scientific works are analyzed. For the theoretical foundation of the manuscript mainly are used books by Bulgarian scientists traditionally working in the field of international economic relations. Agreement within the WTO presents the modes of international supply of services. The practical part is based on analyzes of medical articles which include an overview of doctors from all over the world. Economic business reviews are also taken into account. Statistics from global reports and data from UNWTO and global market research and management consulting company Global Market Insights complete the practical part of the article. Statistics and forecasts from specialized business editions such as "Fortune" are taken into account.

\section{Research Process}

The main objective of the manuscript is to present medical tourism through the prism of international trade. The paper includes theoretical and documentary analysis of international contracts to explain the standard way of supplying medical services. The potential of technologies in medicine is presented as this is a prospect 
for a fundamental change in the way medical services will be provided. The forecast of the article is made on the basis of the pace of technology development. The main sources of quantitative data are statistics and forecasts for the size of medical tourism. The conclusions in the article are made on the basis of a comparison between the separate forecasts for the development of medical tourism and the market of medical technologies.

\subsection{Sampling}

The first phase is a theoretical analysis of the ways of providing tourist services. A hypothesis for possible deviations from the standard forms of trade in medical services is expressed. The development of distance medical services is studied from its inception: the beginning of the 21st century to the present time through descriptive analysis. The progress of medical technologies and services during the last two decades is examined in order to make a forecast for the next two decades if the same trend remains. The article has a theoretical aspect, though the conclusions are made on the basis of practical phenomena.

\subsection{Measures and analysis}

The second phase is constructed on the base of secondary quantitative information for medical tourism covering the period of the last 3 years. Moreover, for the aim of the article different forecasts for 2020-2030 are presented. Qualitative information from medical researches concerning the use of technologies in the treatment process is studied. Quantitative information on forecasts related to the development of technologies in medicine is summarized and compared. On the basis of data for development of technologies in medicine a logical reference about modifications in supplying health care internationally is made.

The third phase is composed by logical causal relations between the theoretical foundation and empirical data. Scientific and technical progress is the prerequisite from which the conclusion about the possible change in the way of providing medical services is made and an opinion for the long-term future of medical tourism is expressed.

\section{Essence of medical tourism as a part of international trade}

International trade is a general form of international economic relations [6], even one of the most important. At the same time, tourism with its diversity contributes significantly for the development of international trade. Medical tourism is part both of national and global tourism, but the motives for its occurrence are radically different from any other type of tourism. The foundation of medical tourism is built on the instinct for preservation of human life which is the greatest value. Cambridge dictionary describes the health service as: "A public service that provides medical treatment. Health services are provided by organizations and activities" [7]. According to Oregon legal glossary the notion "health care services" means: the furnishing of medicine, medical or surgical treatment, nursing, hospital service, dental service, optometrical service, complementary health services or any or all of the enumerated services or any other necessary services of like character, whether or not contingent 
upon sickness or personal injury, as well as the furnishing to any person of any and all other services and goods for the purpose of preventing, alleviating, curing or healing human illness, physical disability or injury [8].

Tourism is an essential part of international trade. It represents a specific sector compared to trade in goods. The product mobility is necessary component in international trade in goods, while in global tourism the mobility is carried out by residents from different countries. Revenues from international tourism enter in GDP in the form of invisible exports [9].

Theoretically, there are several ways in which a medical service could be provided to a foreign resident. In order to carry out medical tourism in its standard form, mobility of buyer (in this case patient) and mobility of seller (doctors) should be available. In order to perform standard medical service, seller and buyer should be in direct contact [10]. Nowadays this is the most common way to provider a medical service. Patients travel to foreign countries for three reasons: to receive better health care, to receive cheaper health care or to be provided with a service which is not available in their own country.

There is another specific way to provide a medical service on the territory of foreign country. This way is connected with opening hospital branches on the territory of a foreign country or the so called 3th mode from GATS [11] - "commercial presence" [12]. Establishment of a commercial presence is another way to supply service in a foreign country, but this is not actually a type of international tourism. From the side of international economic relations opening a branch in foreign country is type of international investment. International medical tourism may be available if a doctor provides a medical service within the territory of a foreign country as an independent professional (consultant, health worker, etc.) or as an employee of a medical service supplier (hospital). This may be a way for the patient to receive health care from a doctor of different nationality and experience on national territory. This is the so called seller's mobility in the context of medical tourism and is defined as a mode 4 from GATS - "movement of natural persons" [13].

\section{Impact of technologies on medical tourism}

Theoretically, in international trade there is another way of suppling services with no mobility of either buyer or seller. Therefore, this is a possible way to provide medical service: during the service production buyer and seller are in two different countries. Despite it is a relatively futuristic concept it is already happening. Highly-developed technologies are needed to trade medical services without buyer and seller mobility. The minimal requirement for performing such a kind of service is presence of a good telecommunication connection (internet) and possession of technological means - a computer with a camera and a microphone.

The simplest way to provide a healthcare service internationally without direct contact between a doctor and a patient is online consultation. In 2020 due to Covid19 , this type of consultation has become normal and the epidemic situation has 
accelerated their use. The most common cases of using this type of medical care are consultations with a personal doctor, as well as sessions with psychologists, psychotherapists and psychiatrists.

Using of the so-called Watson supercomputer is a specific and innovative way to diagnose. Watson is IBM development with system of AI which aims to helps organizations predict future outcomes, automate complex processes and optimize employees' time [14]. One of the areas in which Watson performs very well is medical diagnosis. Regardless of the mistrust, Watson's diagnoses turned out to be more accurate than those of the doctors [15]. The supercomputer makes diagnoses based on data entered from medical tests and patient examinations. This means that in order for a diagnosis to be made, the patient does not need to be in a country possessing Watson technology. Tests can be sent remotely as a result of which a diagnosis appears. In order to provide the service it is not necessary to have medical tourism available in its standard form.

Robotic telesurgery is another type of AI technology that significantly changes the way surgery is performed, improving the surgeon's precision and allows faster patient recovery. Robotic surgery is evolving significantly in recent decades [16]. This is possible due to scientific progress and the improvement of technology. Technology companies create different brands of robotic surgery systems like Micro Hand $S$ and Da Vinci. The world's first telesurgery was made by a team in New York on female patient at a hospital in Strasbourg in 2001. For two-hour-long laparoscopic cholecystectomy the used robotic system was ZEUS [17]. Nowadays. 20 years after the first usage of telesurgery, there is even competition between different types of robotic systems [18].

There are different forecasts in connection with the development of medical tourism and the market of high technologies in medicine. The forecast for the period 2020-2027 is for $12 \%$ growth in medical tourism globally. Meanwhile, in 2018 there is a significant increase of about $33 \%$ in the global market of surgical robots compared to 2016. This shows significant growth in just 2 years.

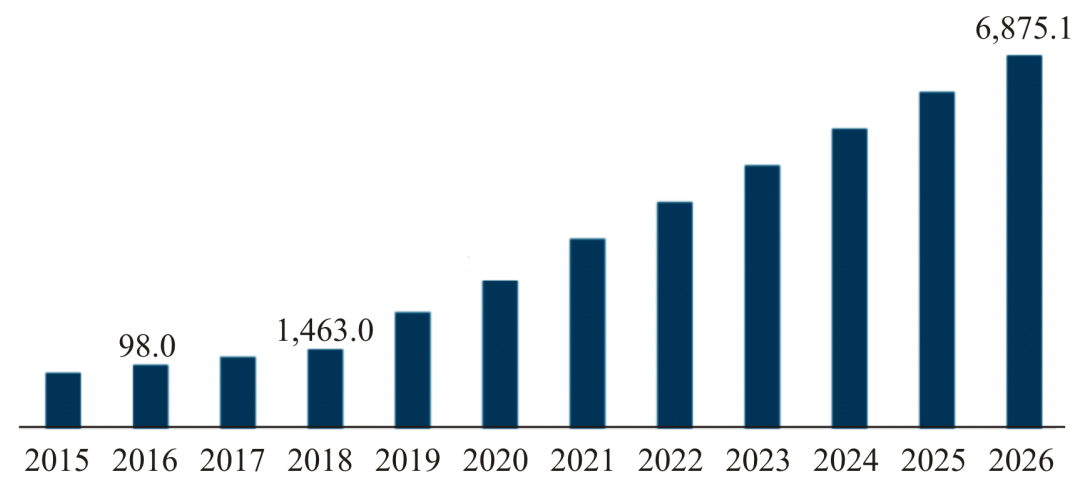

Graph 1: Global Surgical Robots Market Size: 2015-2026 (USD Million) 
For 2018 the revenues from this high medical technology are estimated at $\$ 1,463.0$ million. The absolute market leader holding the impressive share of $\$ 1,045.5$ million is North America. The forecast projects revenues of $\$ 6,875.1$ million for 2026 which means a global growth of about $79 \%$ the surgical robots market in comparison with 2018. The report shows that in 2018 the largest share by application has the General Surgery robots - 28,4\%, followed by Urology, Gynecology and Orthopedics surgery robots [19].

The forecast was published in report from 2019 before the Covid-19 pandemic. This could affect the reliability of the forecast in two ways. On the one hand, slowing down production and reducing demand for a certain period of time of this type of highly expensive technology. On the other hand, the need to limit physical contact between people may be a prerequisite for increased demand of teletreatment. At the same time, hospitals may view the surgical robot technology as a type of long-term investment, so this could justifies the purchase. These factors will affect the market of robotic surgery, but it is unlikely to lead to significant deviations from the projected shares in the forecast.

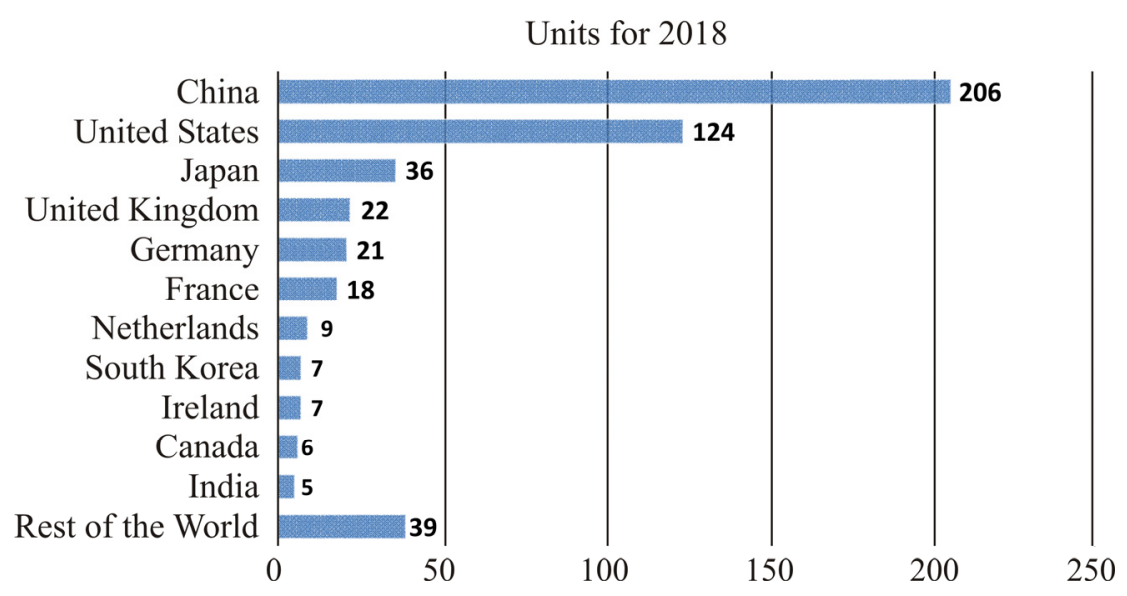

Graph 2: Global distribution of 500 most Powerful Supercomputers

Another market which could affect the future of medical tourism is the market of supercomputers. As mentioned, one of the areas where supercomputers perform better than humans is diagnostics. According to forecasts the potential for growth is estimated at USD 12.51 billion during the period 2021-2025. The year-value-growth rate for 2021 is evaluated at 10,35\% [20]. The compound annual growth rate is predicted to be $9.5 \%$ during the forecast period 2021-2026. From Graph 2 it is visible that the competition between the countries in distribution supercomputers is significant. Europe is dominated by several countries that produce supercomputers (basically by the United Kingdom, France and Germany). However, it is clear that the undisputed leaders in creating supercomputer technology are Asian countries, led by the market giant China. China's main competitor in this field is the United States [21]. 
Currently not every country has such a type of medical technology and specialists who are able to use it. However, there are already countries in the EU that have established good practices in robotic surgery. Among them are Italy, Sweden and Bulgaria [22]. Nowadays the main obstacles for surgical robotics market are the shortage of skilled professionals and a restrictive regulatory framework. However, for the period 2020-2030 a growth of next-generation surgical robotics market is expected [23]. Growth forecasts are an indicator that robotic surgery will gradually become a standard method of operation. As robotic surgery allows remote operations, this will affect the size of medical tourism market over the next few decades.

\section{Findings and Discussion}

Mass penetration challenges of telemedicine are many, but the main obstacles in from of telediagnostics and telesurgery are the lack of capacity and resources of smaller countries. On the one hand, it is the purchase of an expensive technology, which is a serious investment. On the other hand, there is a lack of specialists who can train qualified staff. International professional exchange and investments is the way for faster entry of such technologies and treatment methods from more developed to less developed countries in this medical field.

A good example is the large investment from the world's top healthcare destinations to Bulgaria. Bulgaria is known for the high level of medical education and professional staff, but also with an average level of development of hospital infrastructure and the use of technology. These two factors are a prerequisite for creating a favorable environment for medical investment in the country. In 2016 the Turkish Actbadem Hospitals Group invests 125 million euros to buy a Bulgarian private hospital group Tokuda and acquired a majority stake (76.5\%) in Bulgaria's City Clinic [24]. In addition to buying Tokuda Hospital, the Turkish giant Acıbadem is providing a Da Vinci robotic surgical system. The investment seems to be a profitable venture, as Bulgaria has a tradition in robotic surgery since 2008 and well-trained doctors in the field of oncological gynecology, urology and abdominal surgery. Acıbadem's investment also allows Bulgarian doctors to exchange experiences with their Turkish colleagues, which could accelerate the potential of the Da Vinci robot to be used in areas other than gynecology, urology and abdominal surgery.

Following the example of Acibadem, the faster global implementation of high technologies in countries with smaller capacity can be accelerated. Definitely there is a potential for fundamental change in international trade in medical services.

\section{Conclusion and suggestions}

Remote medical services is a phenomenon that is evolving daily. So far it seems they are something underestimated because it can fundamentally change the international trade in medical services and lead to a significant reduction in medical tourism.

According to data from Table 2, the statistics before COVID-19 shows that most of the medical trips by application are for surgery procedures [25]. Table 3 shows that most Americans travel abroad to treat health problems related to dentistry, cosmetic surgery, 
cardiac conditions, in vitro fertility, weight loss, dermatology, liver and kidney transplants, spine surgery [26]. Currently technologies allow some of these manipulations like liver and kidney transplants, cosmetic and surgery to be performed remotely. Even in dentistry, significant progress is being made with the introduction of AI robotic assistance. Dental services such as consultation and remote monitoring are already available for patients. It is a matter of time before technology develops to the extent that manipulations can be performed distantly. Therefore, this means that much of the medical services will be able to be provided without the need of buyer or seller mobility.

Table 2

Global medical tourism market size, by application, 2016-2017

(USD Million)

\begin{tabular}{|l|c|c|}
\hline \multicolumn{1}{|c|}{ Segment } & 2016 & 2017 \\
\hline Cardiovascular Surgery & $3,315.1$ & $3,670.5$ \\
\hline Cosmetic Surgery & $3,817.7$ & $4,219.2$ \\
\hline Dental Surgery & $2,896.9$ & $3,202.7$ \\
\hline Orthopedic Surgery & $3,204.3$ & $3,585.0$ \\
\hline Bariatric Surgery & $2,855.8$ & $3,132.8$ \\
\hline Fertility Treatment & $1,470.6$ & $1,632.7$ \\
\hline Oncology Treatment & $3,331.7$ & $3,632.8$ \\
\hline Others & $2,326.8$ & $2,573.2$ \\
\hline Total & $23,218.8$ & $25,648.9$ \\
\hline
\end{tabular}

Table 3

The Most Frequent Conditions Treated in Medical Tourists

\begin{tabular}{|c|}
\hline Dentistry \\
\hline Cosmetic surgery \\
\hline Cardiac conditions \\
\hline In vitro fertility \\
\hline Weight loss \\
\hline Dermatology \\
\hline Liver, kidney transplants \\
\hline Spine surgery \\
\hline
\end{tabular}

Positive trends are present in each of the forecasts presented in the exposition of the article. On the one hand, a $12 \%$ increase in medical tourism is expected for the period 2021-2027, which means expected presence of patient mobility. On the other hand, the purchase and implementation of high technology is also with a positive trend. The prediction for the robot surgical market is bold. It is expected to maintain strong growth from the period 2016-2018 (33\%), and from 2018 to 2026 the increase is projected to be $79 \%$ in this market. Expectations for the supercomputer market are also optimistic. For the period 2020-2025 year on year 
growth of $10 \%$ is forecasted. The increased implementation of high technologies is a prerequisite for modification of medical diagnostics and treatment. Robotic surgery and supercomputers are serious financial investments that can bring income not only from the national market. In order to make optimal use of these technologies, it makes sense to export the services internationally. Hence, it is logical to increase the supply of telefiagnostics and teletreatment worldwide.

If remote technologies allow more and more fields of medicine to be manipulated, this will endanger the future development of medical tourism. The procedures will take place from distance and from the point of view of international trade, the supplier country will realize revenues from invisible exports, but there will be no element of tourism and revenues from accompanying the patient's stay services such as transport, accommodation, food and others.

The pandemic situation from 2020 has the potential to be an accelerating factor for the mass exploitation of telediagnostics and telesurgery, as has happened in other sectors of the economy: business, education, culture and even alternative tourism.

In addition to AI development in medicine, the creation of more well-trained doctors and the removal of the restrictive framework, distance medical services may become more widespread in the next 10-15 years. If the evolving pace and the gradual introduction of technologies in medicine until now are taken into account, it will take at least two decades for AI to have a possible negative impact on medical tourism.

\section{References}

1. World tourism barometer and statistical annex. UNWTO, 2020, available at: https://www.e-unwto.org/doi/pdf/10.18111/wtobarometereng.2020.18.1.5 (accessed 10.03.2021).

2. Medical tourism market statistics 2021-2027. Global Report. Available at https://www.gminsights.com/industry-analysis/medical-tourism-market (accessed 10.03.2021).

3. Market analysis report. Medical tourism market size, share \& trends analysis report by country (Thailand, India, Costa Rica, Mexico, Malaysia, Singapore, Brazil, Colombia, Turkey, Taiwan, South Korea, Spain, Czech Republic), and segment forecasts, 2020-2027. Report ID: GVR-2-68038-508-3, 2020, 140 p.

4. Medical tourism market statistics 2021-2027. Global Report. Available at: https://www.gminsights.com/industry-analysis/medical-tourism-market (accessed 10.03.2021).

5. Mawlood F. Top 10 countries for medical tourism - best destinations for treatment. Bookimed, 2020, available at: https://en.bookimed.com/article/top-10medical-tourism-destinations-best-countries-for-treatment (accessed 10.03.2021).

6. Zhelev P. Teoriia na mezhdunarodnite ikonomicheski otnosheniia [Theory on international and economic relations.]. UNWE Publishing Complex, Sofia, 2015, 225 p.

7. Cambridge dictionary. Available at: https:/dictionary.cambridge.org/dictionary/english/health-service (accessed 10.03.2021). 
8. Oregon legal glossary. Available at: https://www.oregonlaws.org/glossary/ definition/health_care_services (accessed 10.03.2021).

9. Danov D. Economics of intellectual products and property rights. UNWE Publishing Complex, 2016.

10. Danov D. Mezhdunarodna t"rgoviia s uslugi i intelektualni produkti [International trade with services and intellectual products]. UNWE Publishing Complex, 2006.

11. GATS: Objectives, coverage and disciplines. Available at https:// www.wto.org/english/tratop_e/serv_e/gatsqa_e.htm (accessed 10.03.2021).

12. WTO: Mode 3-Commercial presence. Available at: https://docs.wto. org/dol2fe/Pages/FE_Search/FE_S_S009DP.aspx?language $=$ E\&CatalogueIList=98186, 73970,108652,45709,45545,64978,72342,39101,11943,30124\&CurrentCatalogueIdIn dex $=0 \&$ FullTextHash $=\&$ HasEnglishRecord $=$ True $\&$ HasFrenchRecord $=$ True $\&$ HasSpani shRecord=True (accessed 10.03.2021).

13. GATS training module: Chapter 1 - Basic purpose and concepts. Available at: https:/www.wto.org/english/tratop_e/serv_e/cbt_course_e/c1s3p1_e.htm (accessed 10.03.2021).

14. IBM official website. Available at: https:/www.ibm.com/watson/about (accessed 10.03.2021).

15. Longoni C., Morewedge C. AI can outperform doctors. So why don't patients trust it? Harvard Business Review, 2019, available at: https://hbr.org/2019/10/aican-outperform-doctors-so-why-dont-patients-trust-it (accessed 10.03.2021).

16. Satava R. How the future of surgery is changing: Robotics, telesurgery, surgical simulators and other advanced technologies. Jurnalul de Chirurgie, 2009, no. 5 (4), pp. 311-325.

17. Choi P., Oskouian R., Tubbs R. Telesurgery: Past, present, and future. Cureus. 2018, no. 10 (5): e2716.

18. Luo D., Liu Y., Zhu H., Li X., Gao W., Li X., Zhu S. \& Yu X. The MicroHand $\mathrm{S}$ robotic-assisted versus Da Vinci robotic-assisted radical resection for patients with sigmoid colon cancer: A single-center retrospective study. Surgical Endoscopy, 2020, vol. 34, pp. 3368-3374.

19. Market research report. Fortune business report: Surgical robot market size, share and industry by application (general surgery, gynecology, urology, orthopedics, others) by end users (hospitals, ambulatory surgery, centers, others) and regional forecast, 2019-2016. 2019, 125 p. Report ID: FBI100948, available at: https:/www.fortunebusinessinsights.com/industry-reports/infographics/surgical-robotsmarket-100948 (accessed 10.03.2021).

20. Supercomputer market. Supercomputer market by end-user, OS, processor type, and geography - forecast and analysis 2021-2025. 2020, 120 p.

21. Mordor Intelligence. Supercomputers market - Growth, Trends, Covid-19 impact, and forecasts (2021-2026). 2020, available at: https://www.mordorintelligence. com/industry-reports/supercomputer-market (accessed 10.03.2021). 
22. Interview with prof. Grigor Gorchev - Manager of St. Marina Hospital in Pleven and honorary rector of the Medical University in Pleven. 2019, available at: https://nes.dir.bg/obshtestvo/zashto-sme-v-top-3-na-evropa-po-robotizirana-hirurgiyachl-kor-prof-grigor-gorchev-pred-dir-bg (accessed 10.03.2021).

23. BIS Research. 2020. Global next-generation surgical robotics market: Analysis and Forecast, 2020-2030.

24. Turkish healthcare group makes 125-mln-euro investment in Bulgaria. 2016, available at: https:/www.hurriyetdailynews.com/turkish-healthcare-groupmakes-125-mln-euro-investment-in-bulgaria-98139 (accessed 10.03.2021).

25. Medical tourism market statistics 2021-2027. Global Report, available at: https:/www.gminsights.com/industry-analysis/medical-tourism-market (accessed 10.03.2021).

26. Dalen J., Alpert J. Medical tourists: Incoming and outgoing. The American Journal of Medicine. Commentary, 2018, vol. 132, iss. 1, p. 9-10.

Оригинальность $92 \%$

Получено 13.04.2021 Принято 05.05.2021 Опубликовано 30.09.2021

\title{
И.Г. Тилева
}

\section{ВЛИЯНИЕ ТЕХНОЛОГИЙ НА БУДУЩЕЕ МЕЖДУНАРОДНОГО МЕДИЦИНСКОГО ТУРИЗМА}

\begin{abstract}
Международный туризм является одним из важнейших секторов мировой экономики. Некоторые страны обязаны большей частью своего валового внутреннего продукта различным видам туризма, в том числе медицинскому. Медицинский туризм не является типичным в одинаковой степени для всех стран. По этой причине лишь некоторые страны классифицируются как направления медицинского туризма. За последние десятилетия развитие технологий преобразило систему здравоохранения. Однако важнейшим объектом анализа является будущее медицинского туризма. Искусственный интеллект выступает источником фундаментальных изменений в сфере оказания медицинских услуг на международном уровне. Более того, пандемия приводит к сокращению международных поездок и меньшей мобильности. Это создает необходимость изменения формата оказания медицинских услуг на международном уровне. Чтобы спрогнозировать, могут ли технологии повлиять на способ оказания медицинских услуг, в статье сделано систематическое обобщение, дан прогноз развития рынка высоких медицинских технологий. Представленные прогнозы, охватывающие период от пяти до десяти лет, позволили сделать заключительные выводы. На основании анализа развития медицинских технологий на предыдущих этапах высказывается мнение о дальнейших перспективах.

Ключевые слова: медицинский туризм, технологии, международная торговля, медицинские услуги, искусственный интеллект, мобильность пациентов, суперкомпьютер, роботизированная хирургия.
\end{abstract}

Ивет Г. Тилева - канд. экон. наук, кафедра международных экономических отношений и бизнеса, Университет национальной и мировой экономики, София, Болгария, e-mail: itileva@unwe.bg.

Received 13.04.2021 Accepted 05.05.2021 Published 30.09.2021 